\title{
SOME NEW NEMATID SAWFLIES FROM COLORADO.
}

BY S. A. ROHWER, BOULDER, COLORADO.

The following descriptions are based principally on material collected by myself during the past summer. One new species is described from the collection of the Colorado Agricultural College; the rest are in my own collection.

Many thanks are due to Professor T. D. A. Cockerell for going over all the descriptions. The work is a contribution from the laboratory of Systematic Zoology in the University of Colorado. I am greatly indebted to Professor C. P. Gillette for the loan of the collections belonging to the Colorado Agricultural College.

The following descriptions of Pontania galls seen at Florissant, Colorado, may be of some use. On Salix brachycarpa, Nutt.: (I) Monothalamous; springing from lower side of leaf; arranged along the midrib; globular; colour pale pinkish ; measurements before maturity $8 \mathrm{~mm}$. (2) Monothalamous; bisecting leaf; attached near petiole in clusters of two to four ; bright rose colour above, pinkish below ; measurements before maturity, I $0-12 \mathrm{~mm}$.; similar to $P$. resinicola, Marl. Another Potania gall on Salix sp., is much like $P$. Bruneri, Marl, but did not bisect the leaf, and was attached along the midrib; only one monothalamous gall on each leaf. The Salix belongs to Longifolice as defined by Dr. Rydberg in his Flora of Colorado (Bul. roo Colo. Agricultural College) and probably is S. exigua.

Pontania leucostoma, n. sp. - $\delta$. Length, $5 \mathrm{~mm}$. Moderately robust; head nearly as wide as thorax; clypeus shallowly, circularly emarginate, lobes broad, rounded; ocellar basin distinct, walls rounded; antennal fovea broad, shallow, elongate; antennæ extending beyond thorax, third and fourth joints equal, fifth shorter; joints somewhat nodose at tips; vertex back of ocelli with a few well-defined punctures; mesothorax above with a few small, more indistinct punctures. Venation of primaries normal; secondaries with the lower discal cell longer and wider than upper, claws deeply notched, inner ray shorter and somewhat slender.

Colour in general shining black; face below antennæ, except two black spots below antennæ, clypeus, labrum, mandibles, except tips which are piceous, posterior angles of pronotum, tegulæ, base of costa, apex of anterior coxæ whitish; posterior orbits, upper orbits, inner orbits narrowly, apex of four hind coxæ, trochanters (coxæ and trochanters are inclined to pallid), meso-femora except a narrow line above, meso-tibia, meta-femora

February, Igo8 
except a broad line above and below, meta-tibia except at apex, venter near apex, and edges of the hypopygium ferrugino-testaceous ; meso-tarsi and palpi brown; hind tarsi black. Wings dusky hyaline; costa, except at base which is white, and stigma yellow-brown; rest of the nervures brown.

Habitat.-Boulder, Colo., May 22, I907 (S. A. Rohwer), on foliage of Populus angustifolia.

In Marlatt's Revision of the Nematinæ (Tech. Ser. No. 3, U. S. Dept. Ag.) this species runs to $P$. pisum, Walsh, but it is not that, and may be separated from it by the short fifth antennal joint, different shape of the clypeus, not having the third cubital quadrate, the black antennæ, black line on femora above, yellowish-brown stigma, etc. It also seems to be related to $P$. glinka, Kincaid, but may be separated from that species by the unequal tarsal claws, the lower margin of the stigma being rounded, etc.

Pontania brachycarpce, n. sp. - $q$. Length, $4 \frac{1}{2} \mathrm{~mm}$. Head almost as wide as thorax; seen from above broadly rectangular; clypeus angularly emarginate, lobes triangular, ocellar basin shallow, the walls broad and rounded; ocellar basin with small, dense punctures; antennal fovea distinct; antennæe stout, extending about to basal plates, fourth and fifth joints equal, third longer ; frontal crest slightly emarginate. Third cubital cell sub-quadrate; upper discal cell of hind wings slightly exceeding the lower; claws deeply notched, the inner ray shorter and somewhat stouter; sheath with long brownish hairs. Colour in general black; clypeus, labrum, mandibles, except tips which are piceous, cheeks, face, somewhat between the antennæ, upper and posterior orbits broadly, inner orbits narrowly, extreme angle of pronotum, tegulæ, coxæ except base, trochanters, femora, tibiæe and tarsi, extreme tip of last dorsal segment, last ventral segment slightly, pale reddish yellow, coxæ and trochanters inclined to pallid; palpi brown; tarsi (especially the posterior ones) and apex of posterior tibiæ infuscate. Wings hyaline; nervures dark brown, costa white at base.

Habitat.-Florissant, Colo., June I6, I907 (S. A. Rohwer) on foliage of Salix brachycarpa.

This species is closely related to $P$. pisum, Walsh, but may be separated by the following characters: Head not so wide as thorax, upper discal cell slightly exceeding the lower, claws with inner ray shorter and stouter; pronotum mostly black. It is also somewhat related to $P$. consors, Marl. (CAN. EnT., Dec., I898), and may be known from it by the subquadrate third cubital, black sheath and venter and the apical half of the abdomen being black. It also has much general resemblance to $P$. leucostoma, 
n. sp., but is smalier, the wings less dusky, the nervures weaker; and upper discal cell of hind wings extends beyond the lower, whereas the lower beyond the upper in $P$. leucostoma.

Pontania megacephala, n. sp.- $\mathrm{\sigma}$. Length, $4 \mathrm{~mm}$. Head wider than thorax; transversely oval; inner orbits parallel; clypeus rather deeply and angularly emarginate, lobes broad, rounded; vertex flat, slightly raised back of ocellar basin shallow, walls rounded; antennal fovea small, round, but distinctly defined; antennæ a little shorter than body, third, fourth and fifth joints equal; last seven joints with dense, short black hairs. Venation normal, except that the third cubital is rather small, claws minutely but evenly cleft.

Colour in general, black; clypeus, labrum, mandibles, except tips which are piceous, cheeks, extreme posterior angles of pronotum, tegulæ, apex of coxæ, white; small indistinct spot on upper orbits, posterior orbits on one side very narrowly, trochanters, femora, except line above on mesoand meta-, and line below on pro-femora (the line on the meta-femora is broad), tibiæ, apex of venter and hypopygium pale reddish-yellow; tarsi (the anterior tarsi are much the same as the tibiæ) brownish; palpi brown. Wings hyaline; nervures brown, costa white at base, stigma pallid at base.

Habitat.-Florissant, Colo., June 16, I907 (S. A. Rohwer), on foliage of Salix brachycarpa.

This species is related to $P$. agilis, Cr., but may be separated by the flatter vertex, broader lobes of the clypeus, claws somewhat deeper cleft and much darker colour. $P$, agilis in general is yellow-ferruginous.

Pontania maura, n. sp.- $q$. Length, $4 \mathrm{~mm}$. Robust. Head much narrower than thorax, small and almost round when seen from the front; clypeus nearly truncate ; ocellar basin with wall rounded : antennal fovea small, round, distinctly defined; antenne as long as head and thorax, fourth and fifth joints equal, third shorter and about equal in length with sixth; vertex rounded; head finely and densely punctured; mesothorax above finely, but not as densely as head, punctured. Venation normal, claws deeply cleft, rays subequal and somewhat diverging.

Colour black, except apex of femora, tibiæ and tarsi, which are pale testaceous ; tarsi, especially the hind ones, infuscate, hind tibiæ somewhat infuscate; ovipositor luteous. Wings very hyaline ; nervures brown, costa, stigma and all the nervures at base of wing pallid, almost hyaline.

Habitat._Florissant, Colo., June I, I 907 (S. A. Rohwer), on foliage of Salix brachycarpa. 
This species is related to $P$. atra, Marl, but may be separated from it by the light nervures of the wings, dark trochanters, claws deeply notched, etc. It is also more robust. It is also related to $P$. unga, Kincaid, but may be separated by the nearly truncate clypeus, the tarsal claws being subequal and diverging, smaller size, light stigma and costa, and veins being paler, etc.

Pontania melanosoma, n. sp. $-q$. Length, $3 \frac{1}{2} \mathrm{~mm}$. Robust; clypeus circularly emarginate, lobes broadly rounded, antennal fovea distinct, circular; ocellar basin indistinctly defined; ocellar regions raised; from lower ocellus running to top of each eye is a broad, shallow furrow; antennæ extending to base of abdomen, third and fifth joints equal, fourth a little longer, head and mesosternum finely and rather densely punctured. Third cubital cell subquadrate, slightly wider at apex than at base ; upper discal cell of hind wings slightly exceeding lower. Claws deeply notched, rays subequal. Sheath broad, slightly emarginate beneath, acuminate at tip ; cerci robust, tapering.

Colour mostly black; clypeus, labrum, mandibles, spot between antennæ, antennæ beneath, except scape, dark brown; a triangular spot on upper orbit fulvous; posterior angles of pronotum, tegula, legs, except bases of coxæ and tip of posterior tibiæ and their tarsi, which are infuscate, reddish-yellow. Wings dusky hyaline, nervures brown, base of stigma and all the nervures as they near the base of wing, white. Clypeus with a few long white hairs.

Habitat.-Fort Collins, Colo., May $\mathbf{3}, \mathbf{1} 899$. Type in the collection of Colorado Agricultural College.

In Marlatt's Revision of the Nematinæ of N. Am., this species runs to $P$. nigrita, Marl, but is easily known from that species by the circular antennal fovea and the black posterior orbits.

Pteronus hypomelas, n. sp.- $q$. Length, $5 \mathrm{~mm}$. Clypeus broadly, shallowly, circularly emarginate, lobes small ; antennal fovea not distinctly defined; ocellar basin with walls rounded; between the ocellar basin and the eye is a rather large impression; frontal crest broken in the middle; antennæ reaching to about the third abdominal segment, third, fourth and fifth joints subequal; head with rather sparse, small punctures; pleura sericeous, claws deeply notched, inner ray somewhat shorter than outer. Third cubital cell twice or nearly twice as wide at apex as at base, two and a half or three times as long as width at base ; outer veins of discal cell of hind wings meeting or upper cell slightly extending beyond lower, lower discal one and a half times as wide as upper; stigma regularly tapering from near base to apex. 
Colour black; lobes of clypeus, labrum, mandibles, tegulæ, legs from middle of femora, last apical segment of abdomen, reddish-ferruginous ; trochanters pallid; palpi brown; upper orbits dark reddish. Wings hyaline; nervures light brown, costa at base and the entire stigma pallid.

Hlabitat.-Florissant, Colo., June I, I 907 (S. A. Rohwer), on foliage of Salix brachycarpa.

In Marlatt's Revision of the Nematinæ of N. Am., this species runs out because of the black venter, but it seems to be related to $P$. atriceps, Marl., and may be separated from it by the black venter, smaller size, the fovea not deep, etc.

Pteronus notatus, n. sp.- - . Length, 5 I $/ 2 \mathrm{~mm}$. Clypeus angularly emarginate, lobes round, antennal fovea deep, narrow, elongate; ocellar basin with walls round; frontal crest broken in the middle; antennæ slender, reaching about to third abdominal segment, joints three, four and five subequal, the third a little curved; sheath broad, obtusely pointed, without any hairs at apex. Claws deeply cleft, inner ray a little shorter than outer. The third cubital cell one and a half times as wide at apex as at base, a little more than twice as long as wide at base; upper discal cell in hind wings extending considerably beyond lower; stigma straight on lower margin until apical third, where it slants abruptly upward.

Colour black, clypeus, labrum, base of mandibles (the tips are piceous), coxæ, except at base of posterior ones, trochanters, posterior angles of pronotum and tegulæ whitish; upper posterior and superior orbits broadly, legs from trochanters, except a thin black line above and below on posterior femora, apical segment of abdomen and sheath somewhat, ferruginous; palpi brown. Wings dusky hyaline; nervures brown, costa and stigma pallid.

Habitat.-Florissant, Colo., June 23, 1907 (S. A. Rohwer), on foliage of Salix brachycarpa.

In Marlatt's Revision of the Nematinæ of N. Am., this species runs out on account of the black venter, but it seems to be near $P$. Coloradensis, Marl, from which it may be separated by the black venter, antennal fovea not being triangular, etc. It is, however, closely related to P. hypomelas, n. sp., but may easily be separated by the following comparison. Other characters also separate these two species:

\section{$P$. hypomelas.}

I. Clypeus broadly, shallowly emarginate, lobes small.

2. Eyes almost round on upper margin. 
3. Stigma tapering from near base to apex. lower.

4. Upper discal cell of hind wings but slightly, if any, exceeding

5. Posterior angles of pronotum black.

$$
\text { P. notatus. }
$$

I. Clypeus angularly emarginate, lobes round.

2. Eyes oval on upper margin.

3. Stigma straight until apical third, when it slants abruptly upwards.

4. Upper discal cell of hind wings extending considerably beyond lower.

5. Posterior angles of pronotum and tegulæ whitish.

$$
\begin{aligned}
& \text { MOSQUITO NOTES.-No. } 6 . \\
& \text { BY c. } \$ \text {. LUDLow, M. sc. }
\end{aligned}
$$

Laboratory of the Office of the Surgeon-General, U. S. Army, Washington, D. C.

(Continued from page 34 .)

In the same sub-family as Cellia flava comes an insect closely related to Chagasia, Cruz., having the outstanding whorls of scales on the lower joints of the antennæ, but lacking the outstanding scales on the thorax, and differing also in that part of the abdomen is scaled.

Chagasia (?) lineata, n. sp.-Head very dark, practically black, as is most of the insect, covered with dark brown and white-forked scales, the latter on the vertex and cephalad part of the occiput, very long slender white scales projecting forward between the eyes, dark bristles near the eyes; antennæ very dark, verticels and pubescence white, basal joint brown, with white upright flat scales, Ist and and joints with white scales, those on the second joint longer, more curved, largely fusiform and outstanding, those on the first joint narrow, flat and more closely appressed; palpi heavily covered with dark brown scales, rather erect near the base, the apex white, and two narrow white bands dividing the remainder into three nearly equal parts; proboscis heavily covered with dark brown scales, tip light; eyes dark, clypeus dark.

Thorax: prothoracic lobes with broad fusiform white scales and dark bristles; mesonotum covered sparsely with broad fusiform white scales arranged in lines, near the nape a few slender curved white scales, most of which project forward, a distinct line of the broad fusiform scales cephalad of and over the wing joint, not especially outstanding, but the scales broader than most of those on the mesonotum, a few scales near

February, 1908 